\title{
The Effect of Using Task-Based Learning Method on Student's Achievement in Reading Comprehension of Descriptive Text.
}

\author{
Muhamad Sofian Hadi ${ }^{1,}$, Muhamad Ihsan Deliansyah ${ }^{1 *}$, \\ 1. English Education Study Program, Faculty of Education Science, Universitas Muhammadiyah Jakarta \\ e-mail: deliansyah.ihsan22@gmail.com \\ (Received: 04-07-2021; Reviewed: 13-08-2021; Accepted: 26-09-2021)
}

\begin{abstract}
Descriptive text is a kind of text with a purpose to give information. The context of this kind of text is the description of a particular thing, animal, person, or others, for instance: our pets or a person we know well. Unfortunately, the students feel hard to find out because no strategy or method is used by the teacher to improve descriptive text so makes the students bored The objective of this research is to find out the effect of task-based learning teaching students' in reading comprehension of descriptive text to XI grade students of MA Darul Ihsan Cibungbulang Bogor. The research used a quantitative method with quasi-experimental design by applying pre-test and post-test design. In this research, the writer only uses one class as the sample by using the purposive sampling technique. In collecting the data, the writer use tests as instrument. The data was analyzed by using a t-test. The result of this research showed that using task-based learning method effective in teaching reading comprehension of descriptive text. It can be seen from the significance t-test from students' pre-test and post-test scores that is 2.450>2.056. Based on the statistical calculation, using task-based learning method reached t calculation of 2.450 which was higher than $t$ table of 2.056 at a significance level of 5\%. It also stated a significant increase in mean score between students' pre-test score (51.8) and post-test score (80). The statistical hypothesis revealed that there were differences between both of tests. Therefore, using task-based learning method can be effective for students' reading comprehension on descriptive text..
\end{abstract}

Keywords : Reading Comprehension, Descriptive Text, Task-based Learning.

\begin{abstract}
Abstrak
Teks deskriptif adalah jenis teks dengan tujuan untuk memberikan informasi. Konteks ayat semacam ini adalah uraian tentang hal tertentu, misalnya binatang, manusia, atau orang lain: piaraan kita atau orang yang kita kenal baik. Sayangnya, para siswa merasa sulit untuk mencari tahu karena tidak ada strategi atau metode untuk membaca teks deskriptif sehingga membuat para siswa bosan. Tujuan dari penelitian ini adalah untuk mencari tahu apakah pembelajaran berbasis tugas mengajarkan pemahaman teks destif untuk siswa kelas XI dari MA Darul Ihsan Cibungbulang Bogor. Penelitian menggunakan metode kuantitatif dengan desain kuasi-eksperimental dengan menerapkan desain pra-tes dan pasca tes. Dalam penelitian ini penulis hanya menggunakan satu kelas sebagai sampel dengan menggunakan teknik sampling yang bertujuan. Dalam mengumpulkan data, penulis menggunakan tes sebagai instrumen. Data dianalisis dengan menggunakan t-test. Hasil riset ini memperlihatkan bahwa menggunakan metode belajar berdasarkan tugas yang efektif untuk mengajar pemahaman membaca tentang teks yang deskriptif. Itu dapat dilihat dari nilai penting — tes dari nilai pra-ujian dan pasca-ujian siswa yaitu 2,450 >2.056. Berdasarkan perhitungan statistik, menggunakan metode pembelajaran berbasis tugas mencapai 2,450 yang lebih tinggi dari tabel t 2,056 pada tingkat makna 5\%. Itu juga menyatakan peningkatan yang signifikan dalam nilai rata-rata antara nilai pra-tes siswa $(51,8)$ dan nilai pasca-ujian (80). Hipotesis statistik mengungkapkan bahwa ada perbedaan antara kedua tes. Hipotesis statistik mengungkapkan bahwa ada perbedaan antara kedua tes. Oleh karena itu, menggunakan metode pembelajaran berdasarkan tugas dapat efektif bagi pemahaman siswa dalam membaca teks deskriptif.
\end{abstract}

Keywords : Pemahaman Membaca, Tesk Deskriptif, Task Based Learning. 


\section{INTRODUCTION}

English-speaking capacity is one of the foremost imperative abilities for understudies since English is the universal dialect spoken within the world of innovation, instruction, politics, commerce, and communication instruments most broadly utilized in the world. Word-language intuition in school educational modules usually incorporates the ability in speaking, listening, reading, and writing. Learning and reading aptitudes are fortifying, whereas talking and writing abilities are profitable. All four abilities are found in schoolwork. One of the abilities that are fundamental for each person to have is reading. Man can get data and broaden his knowledge by reading.

Language learning, especially English, requires that the students first learn and understand the skills of language speaking, listening, reading, and writing. One important aspect of learning a foreign language is the ability to understand good reading. Reading is a process that occurs and is used by readers to obtain messages that researchers wish to convey through the media words or written language (Nani 2014:12). Reading activities in learning English are required of the student as one of the skills that will have an impact on learning English at every level of education. It is absorbed because of the process, reading involves predictive skills, checking, in-depth analysis, forming ideas, and two-way communication between readers and reading. The process of constructing meaning through the dynamic interaction among the reader's existing knowledge, the information suggested by the written language, and the context of the reading 4 situation. Young readers read to learn, to participate in communities of readers, and for enjoyment, (Mayasari, 2017).

The complex process occurs in reading because of the demands of the reader able to integrate critical thinking skills, analytical, and knowledge held within the context of the situation presented meaning of reading material. The ability to combine letters into words is part of reading. In addition, the reader understands the reading does not need to identify the word by word, in the reading but finding meaning from the text.

Each student incorporates a distinctive English capacity, since dialect may be a communication science, so each student must have a distinction in diminishing their English aptitudes to daily life. Particularly within the capacity to be examined. When it comes to perusing, one figure that influences students' capacity to perused too exists at the level of education that the understudy has. In reality, the understudies at the senior high school level still have an issue in comprehending the content since they are not able to recognize the thoughts in reading the content that they have perused. Based on Ur in Soraya (2018:2), There are a few components that cause the understudies to get difficulties in comprehending the content: 1). They are not fascinated by taking part in reading lessons. 2). They have restricted sums of vocabulary, 3 ). They are sluggish to studied the content, 4). They get challenges understanding the content, and 5). They don't have great information about reading aptitudes. (Maslina et al., 2020)

The differences in reading ability can be solved in several ways or methods of learning. Based on literature studies, revealed a theory of English learning methods that are viewed as effective for school use. It is the method of task-based learning invented by j. Willis (1996) in (Marishane \& Motona, 2016) The method of task-based learning is an approach to language learning using duty as the main focus of learning. At this learning, students are required to perform a series of tasks given by teachers both in groups and in pairs and after the task is completed, the teacher will discuss or discuss the language used, then make a correction when 
there is an error and assess the results of the student's work through assigned assignments and do appropriate thing or correct if there are misunderstandings in the learning process. The learning model task-based learning was first brought up by Prabhu (1987) who has the three major activities of pre-task (preparatory), task (meaning-focused), and post task (attending to form). It was then redeveloped by Willis (1996) into the six steps as follows : pre task (input, focus on meaning), task, assess, task, planning, task presentation, and post task (language focus).

The ability of reading comprehension in English is needed not only when a reader is confronted with the discourse. This ability is a fundamental ability to be used in every aspect of life. Being able to read will be helpful in reading the guidelines, the signboard, the procedure for an item, or the announcements in English. Based on the background of the study the problem in this study as follows: 1 . Students had difficulty understanding the concept of reading. 2. Students are required to learn reading materials in english lessons. 3. Students can less apply the reading concept to everyday life. 4 . Lack of learning methods teachers use in the reading activity process.

\section{Method}

In this study, the writer used the quantitative method. It applied a quasi-experimental design to prove the effectiveness of the Task-Based Learning method (TBL) on descriptive text reading comprehension. This research was conducted to XI grade of MA Darul Ihsan Cibungbulang Bogor West Java on second semesters in the academic year 2020/2021. Within the research, the author has chosen one group of pre-test, treatment, and post-test designs. It is chosen based on purposive inspecting. According to Engel and Schutt (2010:96) based on journal (Ness, 2011) in purposive inspecting, each test component is chosen for a reason, as a rule since of the interesting position of the test components. Purposive inspecting may be utilized to look at the viability of a few mediations with clients who have specific characteristics.

The population of this research covered all eleventh-grade students of MA Darul Ihsan in the academic year 2020/2021. It consists of 90 students and is divided into three classes, one class consist of 28, one class consists of 30 students, and one last class consists of 32 students. The sample has been selected by the author which consists of 27 students as sample for the treatment of task-based learning. The type of the test is reading content comprehension within the shape of numerous choices that comprise 20 items with five alternatives in each thing. The test would be taken from the perusing content fabric based on the course reading, and the test would be given for pre-test and post-test of the groups.

Based on analysis of data, the author compared the pre-test and post-test scores. To discover the effect of task-based learning, the author utilized measurement calculation of t-test equation with importance degree 5\% and picked up scores.

\section{Findings}

In this research, before calculating the t-test, the data of the students' pre-test and posttest scores were described in the table below :

Tabel 1. Criteria of students pre-test reading comprehension

\begin{tabular}{ccc}
\hline NO & CLASSIFICATION & RANGE OF SCORE \\
\hline 1. & EXCELLENT & $(90-100) 0$ Student \\
2. & GOOD & $(76-89) 0$ Student
\end{tabular}




\begin{tabular}{ccc}
\cline { 2 - 3 } 3. & ENOUGH & $(66-75) 2$ Student \\
4. & POOR & $(40-65) 24$ Student \\
5. & VERY POOR & $(00-39)$ 1 Student \\
\hline & TOTAL SCORE & 1400 \\
\hline
\end{tabular}

Based on calculated scores in the table above, it could be seen that there was a significant difference between students' pre-tests. there are 2 student's get 70 scores, 3 student's get 65 scores, 5 student's get 60 scores, 2 student's get 55 scores, 8 student's get 50 scores, 3 student's get 45 scores, 3 student's get 40 scores, and 183 student's get 0 , the score from the 20 post-test questions these students were being taught had a mean 51,4 score. The pre-test mean score of the students was 51,8 with the lowest score 00 and 70 was the highest score.

Tabel 2. Pre-test Analysis

\begin{tabular}{ccc}
\hline NO & Analysis & Result \\
\hline 1. & $\sum \boldsymbol{x}$ & 1400 \\
\hline 2. & $\sum \boldsymbol{x}^{2}$ & 77.400 \\
\hline 3. & Determining variable $x^{1}$ & 51,8 \\
\hline 4. & Standard Deviation score of $x^{1}$ & 53.607 \\
\hline
\end{tabular}

Tabel 3. Criteria of students post-test reading comprehension.

\begin{tabular}{ccc}
\hline NO & CLASSIFICATION & RANGE OF SCORE \\
\hline 1. & EXCELLENT & $(90-100) 0$ Student \\
2. & GOOD & $(76-89) 22$ Student \\
3. & ENOUGH & $(66-75) 5$ Student \\
4. & POOR & $(40-65)$ 0 Student \\
5. & VERY POOR & $(00-39) 0$ Student \\
\hline & TOTAL SCORE & 2160 \\
\hline
\end{tabular}

Based on the table above students post-test scores, it can be seen that the lowest score is 75 and the highest score is 85 . There are 5 student's get 85 scores, 17 students get 80 and 5 students get 75 score. The post-test mean score of the students was 80 with the lowest score 75 and 85 was the highest score. The scores from 20 questions of post-test these students were being taught had a mean 80 of score, the scores were higher than the previous score.

Tabel 4. Post-test Analysis

\begin{tabular}{ccc}
\hline NO & Analysis & Result \\
\hline 1. & $\sum \boldsymbol{x}$ & 2160 \\
\hline 2. & $\sum \boldsymbol{x}^{2}$ & 173.050 \\
\hline 3. & Determining variable $x^{1}$ & 80 \\
\hline 4. & Standard Deviation score of $x^{1}$ & 80,06 \\
\hline
\end{tabular}


Tabel 5. Determining t-test, Degress of Freedom,

\begin{tabular}{|c|c|c|}
\hline NO & Analysis & Result \\
\hline 1. & t-test & -2.450 \\
\hline 2. & $d f$ & 26 \\
\hline 2. & $\begin{array}{c}\text { t-Table degree at significance } \\
5 \%\end{array}$ & 2.056 \\
\hline
\end{tabular}

Based on the result analysis was $2.450>2.056$, the result of the data analysis showed that by using the t-test formula, the result of to was 2.450 higher than t-test was 2.056 , which means that the effectiveness of using task-based learning of descriptive text was significant.

Hypothesis Testing

The author proposed the hypothesis as follows: H0 is task-based learning does not give an effect on students' reading comprehension of descriptive text, while H1 is Task-based learning effective on students' reading comprehension of descriptive text. To the prove hypothesis above, the author used the result of the student's pre-test and the post-test score was calculated by t-test and follows the assumption as below if the result calculation is higher than the t-test the positive hypothesis $\mathrm{H} 1$ is accepted and the negative hypothesis $\mathrm{H} 0$ is rejected. As explained above that the result was 2.450 means it was higher than the t-test, 2.056. It means that the use of task-based learning of descriptive text is effective.

\section{Discussion}

Based on the result of the t-test calculation over 2.450 was gotten within the degrees of freedom (df) $27-1=26$. Within the degree of importance $5 \%(2.056)$ was gained. If it is compared to each score within the degree of centrality at that point the result was 2.450>2.056. Since to is higher than the t-test, the positive speculation (H1) can be acknowledged whereas the negative theory (Ho) was rejected. As Pierce (2008:3) clarified that on the off chance that there is less than a $5 \%$ chance that the negative speculation is genuine, dismiss the thought that the negative speculation is genuine, and acknowledge the positive hypothesis. (Nurasiah, 2019)

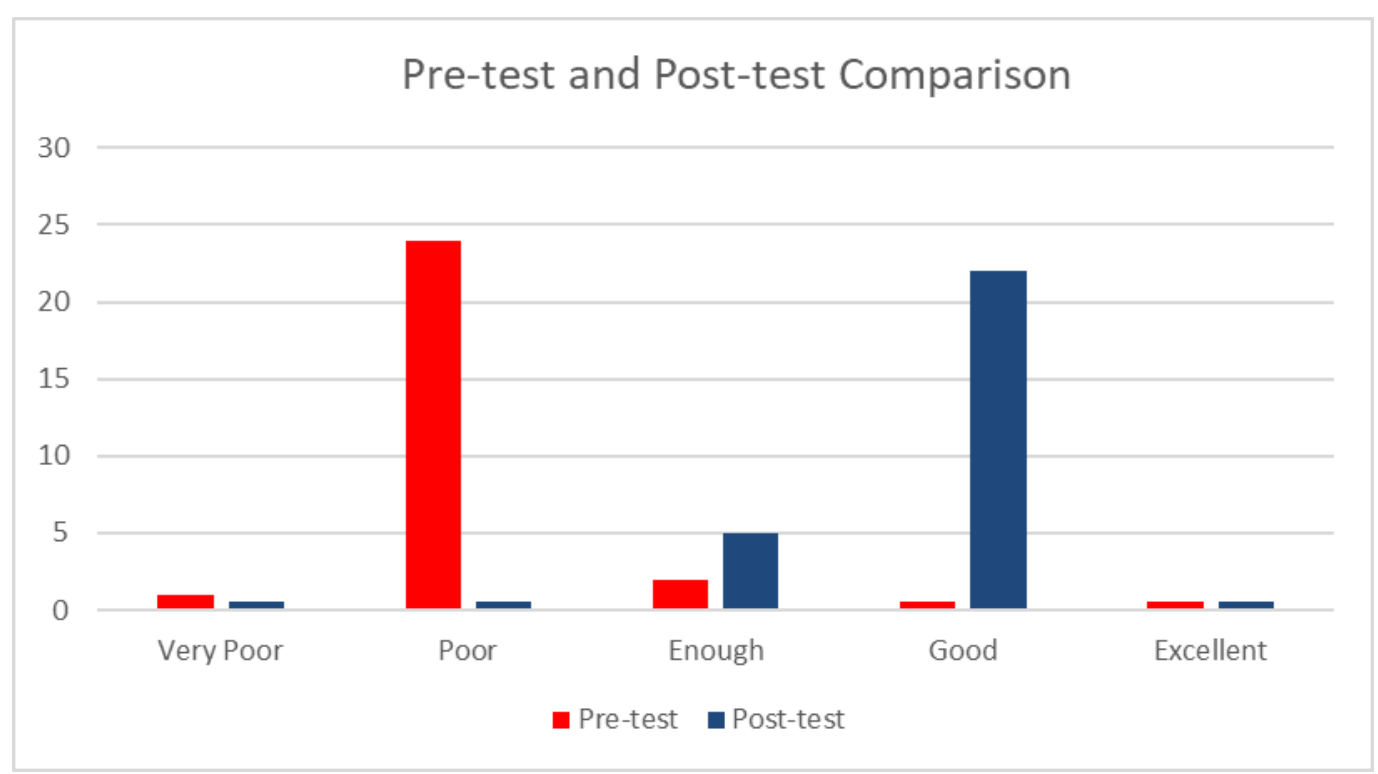

Diagram 1 Comparison of results pre-test and post-test. 
Based on the explanation above, the writer concluded between students' pre-test scores and students' post-test scores after using the task-based learning method was quite a success. At the post-test stage, there were five aspects which were measured in this research, students experienced an increase in reading comprehension in descriptive text in the form of describing text, increasing vocabulary, increasing identification and description of the text being discussed in detail, identifying the main idea, identifying specific information, so that students can feel, see objects presented in detail from the text and questions that have been given. This is evidenced by as many as 22 students who managed to get scores with the classification of 'good' and 5 with the results of the classification of scores 'enough' after previously students only got very 'poor' and 'poor' classifications.

The results from the mean pre-test score are 51,8 while the mean post-test score is 80 . The advancement of the scores was caused by a few variables, such as they were curious about learning reading because they were instructed by employing an unused strategy that was TBL approach, understudies learned perusing more eager and competitive, they delighted in doing the errand since they were dynamic within the teaching-learning prepare, etc. Of course, It demonstrated that students' accomplishment in perusing comprehension expanded. Nunan (2004) describes tasks as activities that can stand alone as fundamental units and involve authentic language comprehension, manipulation, or interaction while emphasizing meanings rather than forms. (Anwar, 2012)

Referring to the findings of the study contained several implications, both practical and theoretical implications for the using task based learning method in English learning reading comprehension of descriptive text in MA Darul Ihsan Cibungbulang Bogor. The application of the task-based learning English learning model will be effective if the teacher's openness and willingness to accommodate student attractions in the selection of duty as well as the selection of a project theme or topic to be done in class. according to Richards and Rodgers (2001) based on a journal (Pradanti \& Sarosa, 1983) put its key theory of learning is as follows: 1) Tasks provide both the input and output processing necessary for language acquisition. 2) Task activity and achievement motivate students to learn and therefore promote learning. 3) Learning difficulty can be negotiated and fine-tuned for particular pedagogical purposes.

Teachers must prepare a variety of fun and exciting tasks because by giving fun and exciting assignments, student involvement, and enthusiasm for learning become much more. The application of a task-based learning method will be effective if a teacher can play the role, both as an organizer at the beginning of the lesson, as well as facilitators, observers, and language advisers during the learning activity. Teachers should be able to encourage and motivate students to participate in the task and be willing to risk reading English without worrying about making mistakes. The application of the task-based learning model will be effective if the task-based principles of active learning, surgery, reproduction to creation, and reflection are used from the stage of learning design to application.

Some studies had been conducted by some researchers related to task based learning in reading comprehension, mostly the previous research found that the use of tasks on learning could give an effect on reading comprehension. Sinaga (2015) found that task based learning can give a positive and significant effect on student's reading comprehension, students who are taught by using task based learning approach are better than the students who are taught by using a conventional approach to reading comprehension. 
Based on the result from research of (Ramadona,Sukirlan, Suka : 2015), there is an improvement of the students' reading comprehension after being taught through task based Learning technique at the second grade of SMPN 10 Bandar Lampung, that can be seen in significant differences of student's score from pre-test and post. It was caused by examining makes a difference the understudies to induce particular data to share in their bunch. On other hand, the least increment was in deciding references.

Students' activation of a proven lesson is better, their preparation in the phase task cycle of task based learning methods is the feedback to the full understanding of materials they have learned and derived after the phase pre-task and report in the task-based learning method. Reading comprehension has some levels of comprehension. In this study, the writer uses Burns' levels of comprehension. Dealing with this result, there are some possible reasons why taskbased learning could influence, according to Burns (1984) based on research Reading Strategies As Development Model English Cognition of Senior High School Students. IJEE (Indonesian Journal of English Education), (Supeno et al., 2017) is divided into four levels; they are literal reading, interpretive reading, critical reading, and creative reading.

\section{Conclusion}

Based on the research that was held on the 11-grade students of MA Darul Ihsan Cibungbulang Bogor, it can be concluded that using the Task-based learning method on student's achievement in reading comprehension of descriptive text is effective. it shows from the results after the task-based learning method is applied are higher than the result before taskbased learning is applied. The result of this research analysis obtained to (t-observation) is 2.450. Meanwhile, $t \mathrm{t}$ (t-table) is 2.056 with a significance of $5 \%$ which means that (t-observation) is higher than $\mathrm{tt}$ (t-table). In the word, the positive hypothesis (H1) is accepted and the negative hypothesis $(\mathrm{H} 0)$ is rejected $(2.450>2.056)$.

Based on the final test data analysis, it seems that the result of students' learning given to the method of task-based learning is higher than that of ordinary students learning. The differences in the results of these studies were an effect of the treatment given to the experiment class. "Task-based learning are activities where the target language is used by the learner for a communicative purpose (goal) to achieve an outcome" as defined by Willis (1996). Thus, it can be said that using the task-based learning method was effective on student's achievement in reading comprehension of descriptive text mastery,(Pratiwi et al., 2015).

\section{References}

Anwar, K. (2012). MENGOPTIMALKAN TASK BASED TEACHING AND LEARNING. Didaktika, 49-56.

Marishane, R. N., \& Motona, J. (2016). Managing Teaching and Learning for Reading English as a First Additional Language. International Journal of Educational Sciences, 14(3), 284293. https://doi.org/10.1080/09751122.2016.11890503

Maslina, Y., Rahmi, R., Studi, P., \& Bahasa, P. (2020). the Use of Small Group Discussion in Teaching Reading Comprehension ( a Descriptive Study At the Second-Semester Students 
of English Department of Stkip Bina Bangsa Getsempena Banda Aceh ). 1(1).

Mayasari, asti et. a. (2017). Improving Student's Reading Comprehension Through QuestionAnswer Relationships. 130-139.

Ness, M. (2011). Explicit reading comprehension instruction in elementary classrooms: Teacher use of reading comprehension strategies. Journal of Research in Childhood Education, 25(1), 98-117. https://doi.org/10.1080/02568543.2010.531076

Nurasiah. (2019). THE EFFECT OF STORY FACE STRATEGY ON STUDENTS ' READING COMPREHENSION OF NARRATIVE TEXT IN GRADE XI OF INFORMATIKA CIPUTAT VOCATIONAL Submitted as Patrial Fullfillment of the Requirements For the Degree of Sarjana Pendidikan ( S. Pd.) ENGLISH EDUCATION.

Pradanti, S. I., \& Sarosa, T. (1983). English Education Department Teacher Training and Education Faculty Sebelas Maret University of Surakarta. 265, 312-318.

Pratiwi, V. U., Astuti, P. I., \& Handayani, S. (2015). Kemampuan Membaca Teks Bahasa Inggris. Magister ScPratiwi, V. U., Astuti, P. I., \& Handayani, S. (2015). Kemampuan Membaca Teks Bahasa Inggris. Magister Scientiae, O(38), 132-142. Https://Doi.Org/10.33508/MGS.V0I38.789ientiae, O(38), 132-142. http://journal.wima.ac.id/index.php/Magister_Scientiae/article/view/789

Supeno, S., Suseno, I., \& Alhamidi, L. A. (2017). Reading Strategies As Development Model English Cognition of Senior High School Students. IJEE (Indonesian Journal of English Education), 4(1), 84-96. https://doi.org/10.15408/ijee.v4i1.4822 